\title{
Inhibition of paclitaxel resistance and apoptosis induction by cucurbitacin B in ovarian carcinoma cells
}

\author{
YINGCHUN QU ${ }^{1}$, PEIFANG CONG ${ }^{1}$, CHENGJIANG LIN ${ }^{1}$, YIHUI DENG $^{2}$, JESSE LI-LING $^{3,4}$ and MEIXIA ZHANG ${ }^{1}$ \\ ${ }^{1}$ Institute of Metabolic Disease Research and Drug Development, China Medical University, Shenyang, Liaoning 110122; \\ ${ }^{2}$ Department of Pharmacy, Shenyang Pharmaceutical University, Shenyang, Liaoning $110015 ;{ }^{3}$ Nanchuan Institute \\ of Biological Research, Joint Key Laboratory for Bioresource Research and Utilization of Sichuan and Chongqing, \\ Chongqing 408400; ${ }^{4}$ Institute of Genetic Medicine, Joint Key Laboratory for Bioresource Research and Utilization \\ of Sichuan and Chongqing, School of Life Science, Sichuan University, Chengdu, Sichuan 610041, P.R. China
}

Received September 25, 2015; Accepted March 9, 2017

DOI: $10.3892 / \mathrm{ol} .2017 .6148$

\begin{abstract}
Ovarian cancer is the leading cause of mortality among all gynecological malignancies. Drug resistance is a cause of ovarian cancer recurrence and low rate of overall survival. There is a requirement for more effective treatment approaches. Cucurbitacin $\mathrm{B}(\mathrm{CuB})$ is an antineoplastic agent derived from traditional Chinese medicinal herbs. Its activity against paclitaxel-resistant human ovarian cancer cells has, however, not yet been established. The purpose of the present study was to investigate the effect and mechanism of $\mathrm{CuB}$ on human paclitaxel-resistant ovarian cancer A2780/Taxol cells. Cell viability was evaluated by a cell counting assay, while cell cycle arrest and apoptosis were assessed by microscopy and flow cytometry, and proteins associated with apoptotic pathways and drug resistance were evaluated by western blotting. The present results demonstrated that $\mathrm{CuB}$ exerts dose- and time-dependent cytotoxicity against the ovarian cancer A2780 cell line, with half-maximal inhibitory concentration $\left(\mathrm{IC}_{50}\right)$ values $0.48,0.25$ and $0.21 \mu \mathrm{M}$ following 24,48 and $72 \mathrm{~h}$ of incubation, respectively. Compared with its sensitive counterpart, A2780, paclitaxel-resistant A2780/Taxol cells had almost identical $\mathrm{IC}_{50}$ values. Cell cycle analysis demonstrated that treatment with $\mathrm{CuB}$ may induce cell cycle arrest at the $\mathrm{G}_{2} / \mathrm{M}$ phase of the cell cycle in the two cell lines. As revealed by Annexin V/propidium iodide-labeled flow cytometry and Hoechst 33258 staining, CuB-induced apoptosis was accompanied by activation of caspase-3 and downregulation of B-cell lymphoma-2. Western blotting demonstrated that $\mathrm{CuB}$ may enhance the expression of p53 and p21 in the two cell lines. $\mathrm{CuB}$ may also downregulate the expression of P-glycoprotein.
\end{abstract}

Correspondence to: Dr Meixia Zhang, Institute of Metabolic Disease Research and Drug Development, China Medical University, 77 Puhe Road, Shenyang, Liaoning 110122, P.R. China

E-mail: mxzhang@cmu.edu.cn

Key words: cucurbitacin B, ovarian cancer, multidrug resistance, P-glycoprotein
These results indicate that $\mathrm{CuB}$ may exert a therapeutic effect on paclitaxel-resistant human ovarian cancer.

\section{Introduction}

Ovarian cancer is the fourth leading cause of cancer-associated mortality in women, with a 5-year survival rate of 25-35\% in Western countries (1). Ovarian cancer often remains undetected until a late stage, and is commonly referred to as a silent killer (2-8). Currently, the standard therapy for advanced ovarian cancer includes surgery and systemic chemotherapy (5,9-11). Since 1990, combined platinum-based agents and paclitaxel (Taxol; Bristol-Myers Squibb, New York, NY, USA) have become the first-line chemotherapy for ovarian cancer $(12,13)$. Despite a high initial sensitivity to chemotherapy and frequent complete clinical response, the majority of patients with advanced-stage tumors may relapse and gradually develop resistance to the majority of chemotherapeutic drugs (14-16). It has not yet been possible to overcome multidrug resistance (MDR) in the clinical settings.

Much effort has been focused on identifying natural compounds that may reverse the MDR phenotype of cancer cells and/or sensitize MDR cancer cells to chemotherapy without undesirable side effects (17-19). Traditional Chinese medicines are excellent starting materials, since they are not only a rich source for diverse chemicals, but have been used in humans for thousands of years (20-22). Recently, certain natural compounds have been shown to be capable of reversing the drug resistance of ovarian cancer (23). Abouzeid et al (24) and Sarisozen et al (25) reported that transferring-targeted combination micelles of curcumin and paclitaxel have a clear synergistic effect against paclitaxel-resistant SK-OV-3TR cells. Yang et al (26) demonstrated that tectorigenin may sensitize paclitaxel-resistant human ovarian cancer cells through downregulating the Akt and nuclear factor- $\kappa \mathrm{B}$ signaling pathways. Li et al (27) revealed that emodin can sensitize paclitaxel-resistant human ovarian cancer cells to paclitaxel-induced apoptosis in vitro. Zhou et al (28) reported that silibinin is able to restore paclitaxel sensitivity in paclitaxel-resistant human ovarian carcinoma cells. 
Cucurbitacin $\mathrm{B}(\mathrm{CuB})$ is a particularly potent member of the triterpenoid family isolated from plants, and has shown anti-proliferative effects on various cancer cells in vitro and in vivo (29). $\mathrm{CuB}$ may induce cell cycle arrest and apoptosis in cancer cells (30-42).

In the present study, the inhibitory effect of $\mathrm{CuB}$ on the paclitaxel-resistant human ovarian cancer A2780/Taxol cell line and its parental A2780 cell line was assessed. To the best of our knowledge, the present study demonstrated for the first time that $\mathrm{CuB}$ inhibits the growth of these two types of cells through induction of cell cycle arrest and apoptosis, by a number of molecular mechanisms.

\section{Materials and methods}

Reagents. CuB (with a purity of 98\%) was obtained from Professor Yihui Deng's laboratory (Department of Pharmacy, Shenyang Pharmaceutical University, Shenyang, China). Primary antibodies directed against B-cell lymphoma-2 (Bcl-2; cat. no. sc-783), caspase-3 (cat. no. sc-271028), p53 (cat. no. sc-126), p21 (cat. no. sc-6246), P-glycoprotein (P-gp; cat. no. sc-8313) and $\beta$-actin (cat. no. sc-130300) were purchased from Santa Cruz Biotechnology, Inc. (Dallas, TX, USA). Secondary antibodies directed against rabbit (Peroxidase Conjugated AffiniPure Goat Anti-rabbit IgG (cat. no.ZB-2301), or mouse (Peroxidase Conjugated AffiniPure Goat anti-mouse IgG (cat. no. ZB-2305) were from ZSGB-BIO (Beijing, China). The ECL Western Blotting Detection reagent was purchased from GE Healthcare Life Sciences (Chalfont, UK). Dulbecco's modified Eagle's medium (DMEM), RPMI-1640 medium and fetal bovine serum (FBS) were obtained from Thermo Fisher Scientific, Inc. (Waltham, MA, USA). The Annexin V-fluorescein isothiocyanate (FITC) apoptosis detection kit, propidium iodide (PI), Hoechst 33258, dimethyl sulfoxide (DMSO) and other reagents were purchased from Sigma-Aldrich (Merck KGaA, Darmstadt, Germany).

Cell cultures. Ovarian carcinoma A2780 and paclitaxel-resistant A2780 (A2780/Taxol) ovarian carcinoma cell lines were purchased from Nanjing KeyGen Biotech Co., Ltd. (Nanjing, China). Cells were maintained in DMEM (A2780) or RPMI-1640 with $800 \mathrm{ng} / \mathrm{ml}$ paclitaxel (A2780/Taxol) supplemented with $10 \% \mathrm{FBS}, 100 \mathrm{U} / \mathrm{ml}$ penicillin and $100 \mu \mathrm{g} / \mathrm{ml}$ streptomycin. The cells were cultured in a humidified atmosphere containing $5 \% \mathrm{CO}_{2}$ at $37^{\circ} \mathrm{C}$.

Cell viability assay. The viability of A2780 and A2780/Taxol cells was evaluated by counting the numbers of viable cells at 24,48 and $72 \mathrm{~h}$ following the addition of $10 \mu \mathrm{l} \mathrm{CuB}$ to achieve final concentrations of $0.0625,0.125,0.25,0.5$ and $1 \mu \mathrm{M}$. The cells were stained with Trypan Blue and counted using a hemocytometer. The final concentration of $0.5 \%$ DMSO produced no inhibition of cell growth. At least three replicate experiments were performed with three wells per concentration.

Cell cycle analysis. A total of $8 \times 10^{5} \mathrm{~A} 2780 /$ Taxol cells and their parental A2780 cells were incubated with 0.0625, 0.125, 0.25, 0.5 or $1 \mu \mathrm{M} \mathrm{CuB}$ or DMSO for $24 \mathrm{~h}$. The cells were harvested, washed with iced-cold PBS and fixed in $70 \%$ ethanol at $-20^{\circ} \mathrm{C}$ for $24 \mathrm{~h}$. Subsequently, cells were washed with PBS and resuspended in PBS containing $100 \mu \mathrm{g} / \mathrm{ml}$ PI (Sigma-Aldrich; Merck KGaA), $50 \mu \mathrm{g} / \mathrm{ml}$ ribonuclease A and $0.1 \%$ Triton X-100 in the dark for $30 \mathrm{~min}$ at $37^{\circ} \mathrm{C}$. Flow cytometry analysis was performed on a FACSCalibur instrument (BD Biosciences, Franklin Lakes, NJ, USA) using the ModFit LT program (version 3.0; BD Biosciences).

Annexin V/PI staining. Apoptosis of the cells was detected with an Annexin V-FITC Apoptosis Detection kit (Sigma-Aldrich; Merck KGaA). Annexin V-FITC is a sensitive probe for identifying cells undergoing apoptosis, as phosphatidylserine exposure occurs early in the apoptotic process. PI is a non-specific DNA dye that is excluded from live cells with intact plasma membranes, but can be incorporated into non-viable cells. Upon detection, single-positive populations may present as early apoptotic (Annexin $\mathrm{V}^{+} / \mathrm{PI}^{-}$) or necrotic cells (Annexin $\mathrm{V}^{-} / \mathrm{PI}^{+}$), whereas double-positive populations (Annexin $\mathrm{V}^{+} / \mathrm{PI}^{+}$) are indicative of late stage apoptosis (43).

Hoechst 33258 staining. A2780/Taxol and parental A2780 cells $\left(3 \times 10^{5}\right.$ cells) were grown on coverslips placed on 6 -well plates at $37^{\circ} \mathrm{C}$ overnight. Following $0.25,0.5$ and $1 \mu \mathrm{M} \mathrm{CuB}$ treatment, the cells were fixed with methanol and acetic acid $(3 / 1 \mathrm{v} / \mathrm{v})$ at $4^{\circ} \mathrm{C}$ for $15 \mathrm{~min}$, and stained with Hoechst 33258 for $30 \mathrm{~min}$ in the dark at $37^{\circ} \mathrm{C}$. Subsequent to washing in PBS 3 times, the cells were mounted with a medium containing 80\% glycerol (cat. no. G5516; Sigma-Aldrich; Merck KGaA) in PBS. The processed cells were then observed under a fluorescence microscope with 3 fields of view (magnification, $\mathrm{x} 40$; Olympus Corporation, Tokyo, Japan).

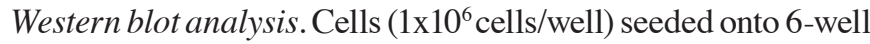
plates were treated with $0.0625,0.125,0.25,0.5$ and $1 \mu \mathrm{M} \mathrm{CuB}$ or DMSO. The medium was aspirated, and the cells were washed with cold PBS. They were then scraped, washed twice with cold PBS followed by centrifugation at $1,000 \mathrm{xg}$ for $5 \mathrm{~min}$ at $4^{\circ} \mathrm{C}$. The pellet was resuspended in lysis buffer supplemented with proteases and phosphatase inhibitors (cat. no. P8340; Sigma-Aldrich; Merck $\mathrm{KGaA}$ ) and incubated for $1 \mathrm{~h}$ at $4^{\circ} \mathrm{C}$. The lysate was collected by centrifugation at $14,000 \mathrm{x}$ for $40 \mathrm{~min}$ at $4^{\circ} \mathrm{C}$, and the supernatant was stored at $-20^{\circ} \mathrm{C}$. For western blot analysis, $50 \mu \mathrm{g}$ proteins were resolved in $8-10 \%$ PAGE and transferred to polyvinylidene difluoride membranes. The blot was blocked with a blocking buffer (5\% nonfat dry milk/0.1\% Tween-20 in TBS) for $1 \mathrm{~h}$ at room temperature, and next incubated with appropriate primary antibodies directed against Bcl-2 (1:200), caspase-3 (1:200), p53 (1:1,000), p21 (1:1,000), P-gp (1:200) or $\beta$-actin $(1: 1,000)$ overnight at $4^{\circ} \mathrm{C}$. The blots were then incubated with horseradish peroxidase-conjugated secondary antibodies (1:1,000-2,000) for $2 \mathrm{~h}$ at room temperature and detected with enhanced chemiluminescence, and protein levels were quantified using a Tanon 5200 Chemiluminescent Imaging system (version 1.02; Tanon Science and Technology Co., Ltd., Shanghai, China). $\beta$-actin was detected on the same membrane and used as loading control.

Evaluation of multidrug resistance in ovarian cancer cells. The multidrug resistance of ovarian cancer cells was evaluated by the cell count and P-gp expression. A2780/Taxol and A2780 cells at a density of $8 \times 10^{5}$ cells/well were cultured with 

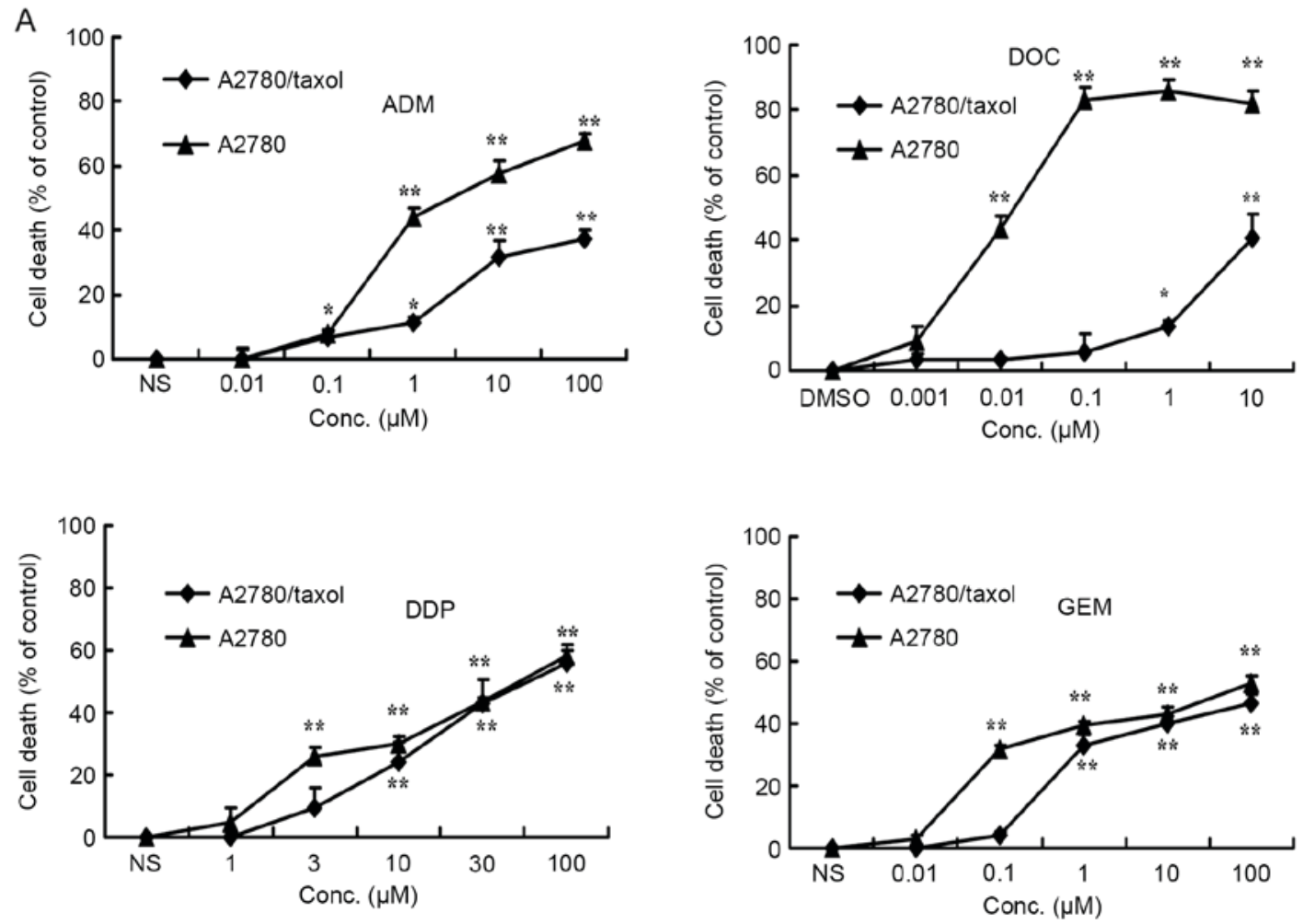

B

A2780

A2780/taxol
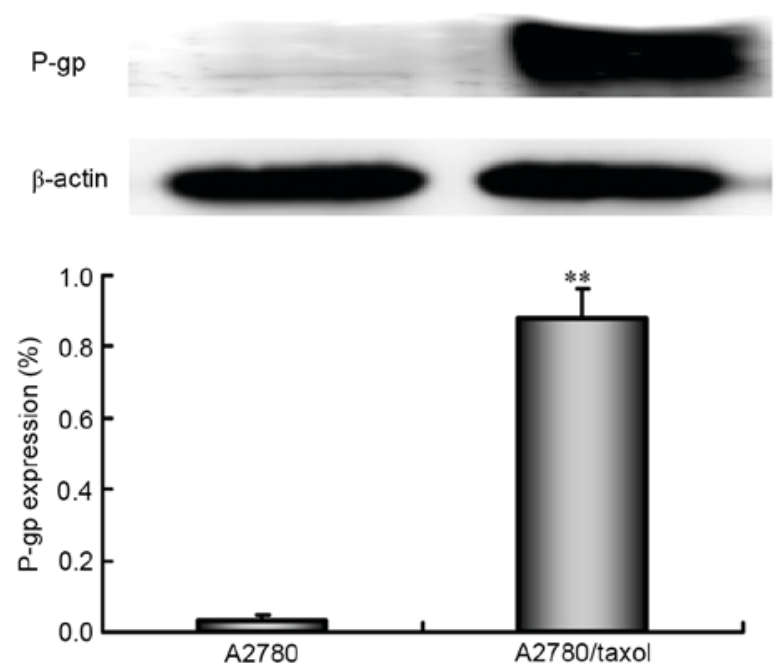

Figure 1. Evaluation of multidrug resistance in ovarian cancer cells. A2780/Taxol and A2780 cells at a density of 8x $10^{5}$ cells/well were cultured with docetaxel $(0.001,0.01,0.1,1$ and $10 \mu \mathrm{M})$, doxorubicin $(0.01,0.1,1,10$ and $100 \mu \mathrm{M})$, cisplatin $(1,3,10,30$ and $100 \mu \mathrm{M})$ and gemcitabine $(0.01,0.1,1,10$ and $100 \mu \mathrm{M})$ for $24 \mathrm{~h}$. (A) The viability of the cells was determined by a cell counting assay. Each point represents the mean \pm standard deviation of three independent experiments. ${ }^{*} \mathrm{P}<0.05,{ }^{* *} \mathrm{P}<0.01$. (B) P-gp expression in A2780/Taxol and A2780 cells. Each point represents the mean of three independent experiments. ${ }^{* *} \mathrm{P}<0.01$ compared with the control. DOC, docetaxel; GEM, gemcitabine; ADM, doxorubicin; DDP, cisplatin; P-gp, P-glycoprotein; Conc, concentration.

docetaxel $(0.001,0.01,0.1,1$ and $10 \mu \mathrm{M})$, doxorubicin $(0.01$, $0.1,1,10$ and $100 \mu \mathrm{M})$, cisplatin $(1,3,10,30$ and $100 \mu \mathrm{M})$ and gemcitabine $(0.01,0.1,1,10$ and $100 \mu \mathrm{M})$ for $24 \mathrm{~h}$. The viability of the cells was determined using a cell counting assay.

Statistical analysis. All values are expressed as the mean \pm standard deviation. Comparison between groups was analyzed by one-way analysis of variance followed by Fisher's least significant difference test using SPSS software (version 16.0; SPSS, Inc., Chicago, IL, USA). Two-sided $\mathrm{P}<0.05$ was considered to indicate a statistically significant difference.

\section{Results}

Evaluation of MDR in A2780/Taxol cells. The MDR of A2780/Taxol cells was evaluated by treating the A2780 and A2780/Taxol cells with docetaxel $(0.001,0.01,0.1,1$ and $10 \mu \mathrm{M})$, doxorubicin $(0.01,0.1,1,10$ and $100 \mathrm{mM})$, cisplatin $(1,3,10,30$ and $100 \mu \mathrm{M})$ and gemcitabin $(0.01,0.1,1,10$ and $100 \mu \mathrm{M})$. As shown in Fig. 1A, the A2780/Taxol cells were resistant not only to docetaxel [A2780/Taxol, half-maximal inhibitory concentration $\left(\mathrm{IC}_{50}\right)>10 \mu \mathrm{M}$ vs. $\left.\mathrm{A} 2780, \mathrm{IC}_{50}=0.11 \pm 0.22 \mu \mathrm{M}\right]$, but also to the common chemotherapeutic drug doxorubicin (A2780/Taxol, 
$\mathrm{IC}_{50}>100 \mu \mathrm{M}$ vs. $\left.\mathrm{A} 2780, \mathrm{IC}_{50}=8.30 \pm 2.50 \mu \mathrm{M}\right)$. However, such cells exhibited no resistance to cisplatin (A2780/Taxol, $\mathrm{IC}_{50}=41.53 \pm 7.48 \mu \mathrm{M}$ vs. $\left.\mathrm{A} 2780, \mathrm{IC}_{50}=42.52 \pm 14.47 \mu \mathrm{M}\right)$ or gemcitabine (A2780/Taxol, $\mathrm{IC}_{50}=20.40 \pm 3.16 \mu \mathrm{M}$ vs. A2780, $\left.\mathrm{IC}_{50}=18.19 \pm 2.47 \mu \mathrm{M}\right)$ at high concentrations. Compared with A2780 cells, A2780/Taxol cells displayed an increase of 90.91- and 12.05-fold resistance to docetaxel and doxorubicin, respectively. By western blot analysis, the paclitaxel-resistant A2780/Taxol cells also exhibited elevated P-gp protein expression compared with A2780 cells (Fig. 1B).

Inhibition of the viability of A2780/Taxol and A2780 cells by $C u B$. A2780/Taxol and A2780 cells were treated with $0.0625-1 \mu \mathrm{M}$ of $\mathrm{CuB}$ for $24-72 \mathrm{~h}$, and cell proliferation was measured by counting the number of viable cells. As shown in Fig. 2, cell proliferation was inhibited by $\mathrm{CuB}$ in a doseand time-dependent manner. Similar $\mathrm{IC}_{50}$ values for $\mathrm{CuB}$ in the two cell lines were derived $\left(\mathrm{IC}_{50}=0.27 \mu \mathrm{M}\right.$ after $72 \mathrm{~h}$ or $0.35 \mu \mathrm{M}$ after $48 \mathrm{~h}$ for A2780/Taxol cells, and $\mathrm{IC}_{50}=0.21 \mu \mathrm{M}$ after $72 \mathrm{~h}$ or $0.25 \mu \mathrm{M}$ after $48 \mathrm{~h}$ for A2780 cells). These results indicated that $\mathrm{CuB}$ has a potent anti-proliferative effect on ovarian cancer cells, regardless of whether they had resistance to paclitaxel (Fig. 2).

Effect of $\mathrm{CuB}$ on the cell cycle. A2780/Taxol and A2780 cells were treated with various concentration of $\mathrm{CuB}$ for $24 \mathrm{~h}$. Following PI staining, the population in various phases of the cell cycle was determined by fluorescence-activated cell sorting (FACS) analysis. As shown in Fig. 3A, the percentage of $\mathrm{G}_{2} / \mathrm{M}$ phase cells had increased from $8.49 \pm 0.95 \%$ in the control cells to $55.22 \pm 2.10 \%(1 \mu \mathrm{M} \mathrm{CuB})$ in $\mathrm{A} 2780$ cells, and from $12.34 \pm 1.66 \%$ in DMSO-treated to $43.47 \pm 2.61 \%(1 \mu \mathrm{M}$ $\mathrm{CuB}$ ) in A2780/Taxol cells.

Effect of $C u B$ on cell apoptosis. As shown by FACS, there appeared to be a dose-dependent increase in apoptotic cells in CuB-treated samples compared with the controls. The proportion of apoptotic cells increased from $2.03 \pm 0.23$ to $11.57 \pm 2.03 \%$, and from $1.37 \pm 0.44$ to $8.77 \pm 1.24 \%$ in A2780 and A2780/Taxol cells, respectively ( $\mathrm{P}<0.01$; Fig. 3B). In addition, marked morphological changes suggestive of apoptosis, including chromatin condensation, nuclear fragmentation and apoptotic bodies, were observed by Hoechst 33258 staining (Fig. 3C).

Effect of $C u B$ on the expression of p53 and $p 21$. The present study investigated whether $\mathrm{CuB}$ modulates the expression of p53 and p21 in ovarian cancer cells. As shown in Fig. 4A, $\mathrm{CuB}$ treatment could upregulate the expression of p53 and p21 in a dose-dependent manner. Treatment of A2780/Taxol and $\mathrm{A} 2780$ cells with $0.25 \mu \mathrm{M} \mathrm{CuB}$ for $24 \mathrm{~h}$ significantly upregulated the expression of the p21 $(\mathrm{P}<0.05)$, while $\mathrm{CuB}$ significantly upregulated the expression of the $\mathrm{p} 53$ at $0.5 \mu \mathrm{M}$ (P<0.05; Fig. 4A).

Effect of $C u B$ on the expression of $B c l-2$ and caspase-3. $\mathrm{Bcl}-2$ is an important member of the Bcl-2 family of proteins, which regulate cell apoptosis (44). Bcl-2 is considered an important anti-apoptotic protein and is classified as an oncogene (45). As shown in Fig. 4A, Bcl-2 is expressed in A2780/Taxol
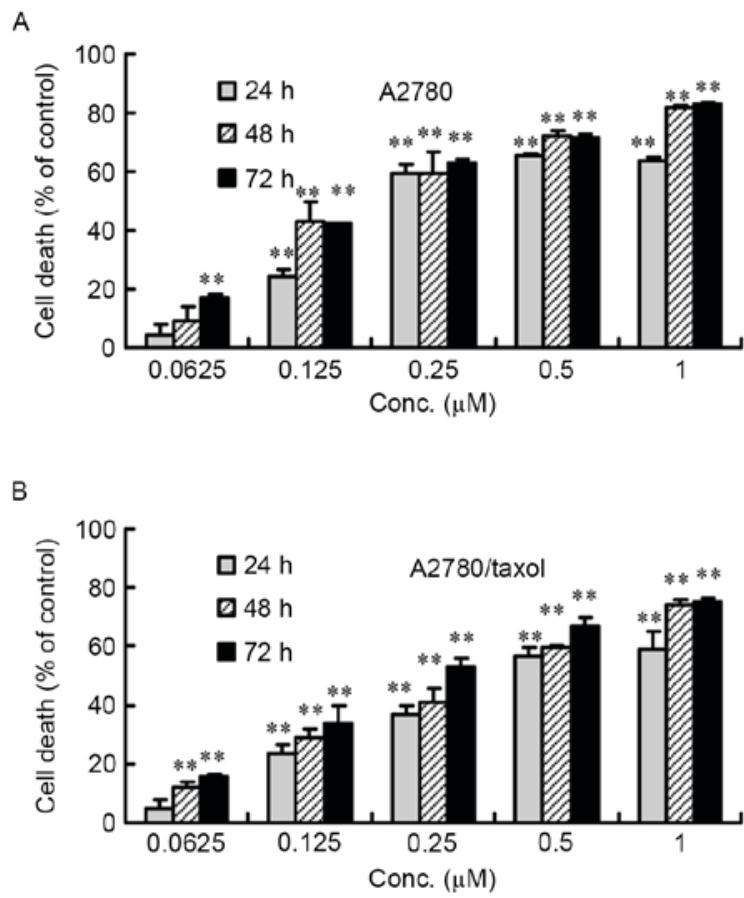

Figure 2. Cytotoxic effect of $\mathrm{CuB}$ on paclitaxel-resistant ovarian cancer A2780/Taxol cells and their parental A2780 cells. (A) A2780 and (B) A2780/Taxol cells at a density of $8 \times 10^{5}$ cells/well were cultured with various concentrations of $\mathrm{CuB}$ for 24,48 and $72 \mathrm{~h}$. The viability of the cells was determined daily by a cell counting assay. Each point represents the mean \pm standard deviation of three independent experiments. ${ }^{* *} \mathrm{P}<0.01$ compared with the control. CuB, cucurbitacin B; Conc, concentration.

and $\mathrm{A} 2780$ cells, and $\mathrm{CuB}$ could suppress Bcl-2 expression in a dose-dependent manner. In addition, $\mathrm{CuB}$ treatment significantly decreased the intensity of pro-caspase- 3 expression (Fig. 4A).

Effect of $C u B$ on P-gp expression. P-gp is an important protein of the cell membrane, which pumps various foreign substances out of the cell (19). P-gp is responsible for decreased drug accumulation in MDR cells, and can mediate the development of resistance to anticancer drugs (46). The present study determined whether $\mathrm{CuB}$ downregulates the expression of P-gp in A2780/Taxol cells. As confirmed by western blot analysis, $\mathrm{CuB}$ treatment suppressed the expression of P-gp in the A2780/Taxol cell line in a dose-dependent manner (Fig. 4B).

\section{Discussion}

The high mortality of ovarian cancer is usually due to the failure of early detection and lack of effective therapies for late-stage cancers $(3,5)$. The standard therapy for advanced ovarian cancer consists of extensive surgical resection followed by combination chemotherapy with paclitaxel/carboplatin (47). However, such drugs frequently induce resistance (48). Recently, natural compounds with a high potential and relatively low toxicity have been explored for use as single agents or in combination with a conventional chemotherapeutic agent (24). For instance, curcumin isolated from curry spice has been demonstrated to potentiate the antitumor activity of various chemotherapeutic agents in a 
A
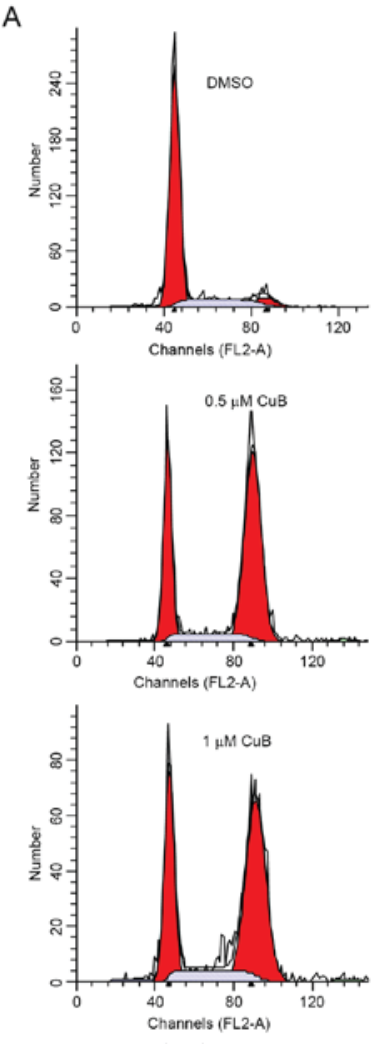

- $G 10 \mathrm{a} \mathrm{aG}_{\mathrm{G}}$

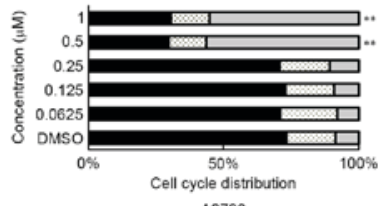

A2780
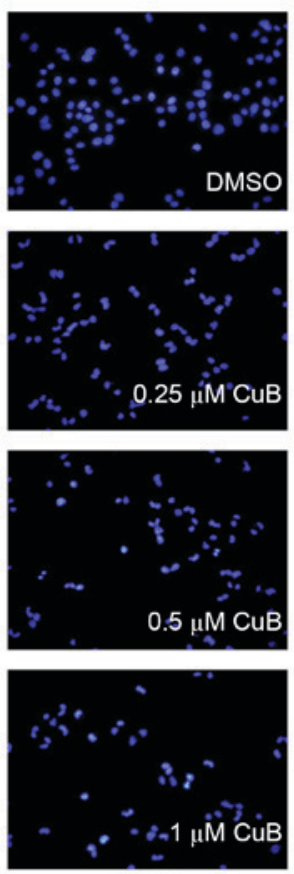

A2780
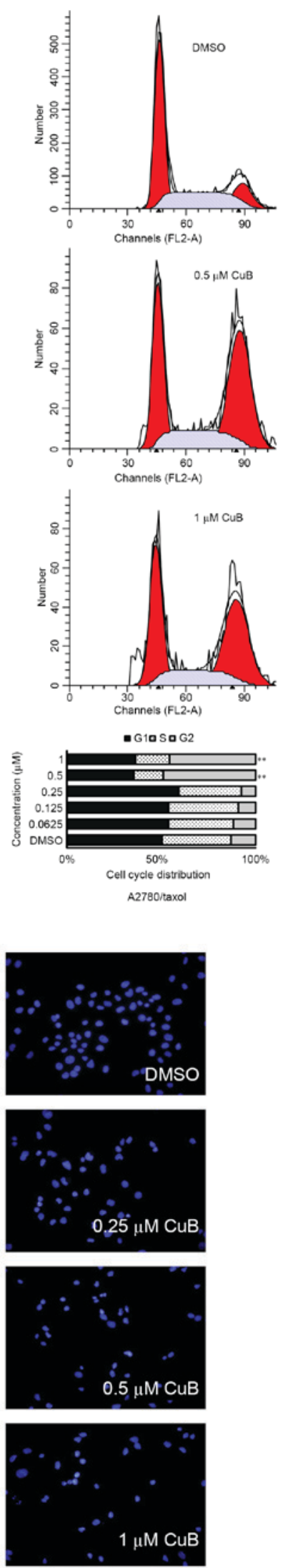

A2780/taxol
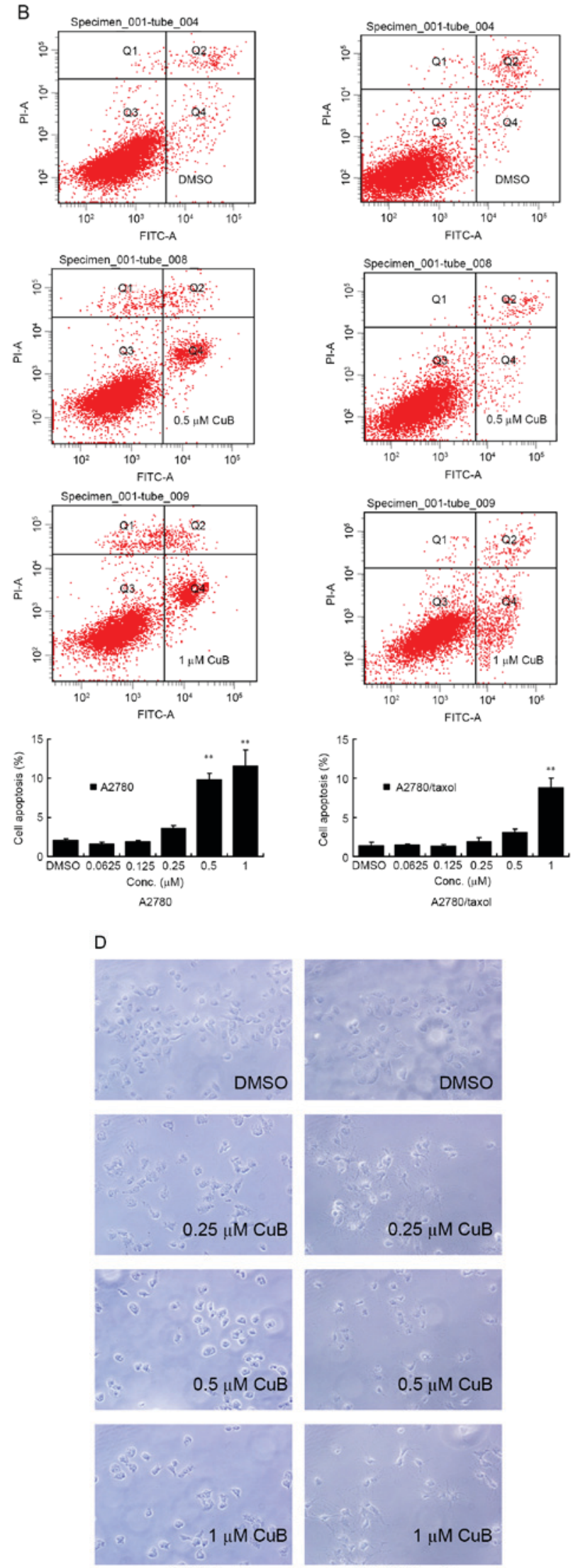

$\mathrm{A} 2780$

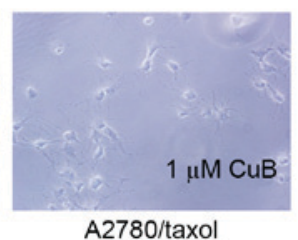

Figure 3. Effect of $\mathrm{CuB}$ on cell cycle distribution and apoptosis induction. A2780/Taxol and A2780 cells $\left(1 \times 10^{6}\right)$ were treated with various concentrations of $\mathrm{CuB}$ for $24 \mathrm{~h}$. (A) Cell cycle analysis by flow cytometry. The percentage of G2/M phase cells increased from $8.49 \pm 0.95 \%$ in the control DMSO group to $55.22 \pm 2.10 \%$ in A2780 cells treated with $1 \mu \mathrm{M} \mathrm{CuB}$, and from $12.34 \pm 1.66 \%$ in the control DMSO group to $43.47 \pm 2.61 \%$ in $\mathrm{A} 2780 /$ Taxol cells treated with $1 \mu \mathrm{M}$ CuB.** $<0.01$ compared with the control. (B) Apoptosis analysis by flow cytometry. As shown by FACS, there appeared to be a dose-dependent increase in apoptotic cells in CuB-treated samples compared with the controls. The proportion of apoptotic cells increased from $2.03 \pm 0.23$ to $11.57 \pm 2.03 \%$, and from $1.37 \pm 0.44$ to $8.77 \pm 1.24 \%$ in A2780 and A2780/Taxol cells, respectively. ${ }^{* *} \mathrm{P}<0.01$ compared with the control. (C) Cells with Hoechst 33258 staining (magnification, $\mathrm{x} 40$ ). (D) Cell morphology under light microscopy (magnification, $\mathrm{x} 40$ ). CuB, cucurbitacin; DMSO, dimethyl sulfoxide; FITC, fluorescein isothiocyanate; PI, propidium iodide; Conc, concentration. 
A

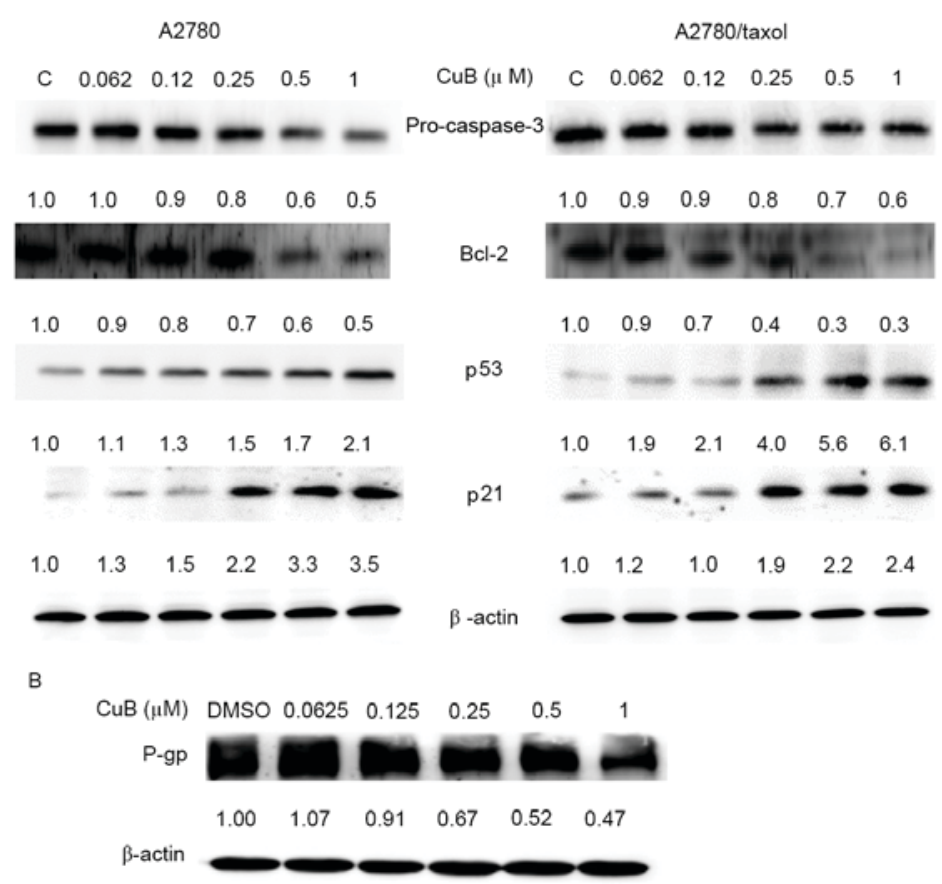

Figure 4. Western blot analysis of Bcl-2, p53, p21, caspase-3 and P-gp protein expression. (A) A2780 and A2780/Taxol cells were treated with various concentrations of $\mathrm{CuB}$ for $24 \mathrm{~h}$, and the protein expression of Bcl-2, p53, p21 and caspase-3 was analyzed. (B) A2780/Taxol cells were treated with various concentrations of $\mathrm{CuB}$ for $24 \mathrm{~h}$, and the protein expression of $\mathrm{P}$-gp was analyzed. Upon CuB treatment, the cells were harvested and processed for western blotting. $\beta$-actin was used as an internal control. Immunoblots are representative of three independent experiments. Bcl-2, B-cell lymphoma 2; CuB, cucurbitacin; C, DMSO; P-gp, P-glycoprotein.

wide range of cancer cells, including drug-resistant ovarian cancer $(24,25,49,50)$.

$\mathrm{CuBs}$ are isolated from various plants, which have been used as folk medicines in countries such as China and India (32). In recent years, their anti-proliferative effect has been demonstrated on a variety of cancer cells by in vivo and in vitro experiments $(32,35,42,51)$. The present study confirmed that $\mathrm{CuB}$ also has an inhibitory effect on the growth of paclitaxel-resistant A2780/Taxol cells and their parental A2780 cells in a dose- and time-dependent manner. Through a series of experiments, it was demonstrated that $\mathrm{CuB}$ treatment resulted in the accumulation of cells at the $G_{2} / M$ phase of the cell cycle. $\mathrm{CuB}$ could also induce cell apoptosis in a dose-dependent manner. These results indicated that the inhibitory effect of $\mathrm{CuB}$ on paclitaxel-resistant A2780/Taxol cells was due to the induction of cell cycle arrest as well as apoptosis.

MDR is the major cause of failure in anticancer treatment (19). The mechanisms associated with MDR may be classified into two major categories: Pump (P-gp) resistance and non-pump (apoptosis) resistance (52). The former is mainly caused by overexpression of the P-gp protein, which is capable of reducing the intracellular accumulation of drugs by expelling the drugs outside of the cell (53). This may lead to resistance to a wide range of anticancer drugs, including doxorubicin, vinblastine, dactinomycin and paclitaxel (54-56). Approximately $50 \%$ of human cancers overexpress P-gp at levels sufficient to confer MDR (56-59). Through the present study, it was demonstrated that the MDR of A2780/Taxol cells may be in part attributed to overexpression of the P-gp protein, while CuB may significantly inhibit P-gp expression.
The non-pump resistance mechanism is the result of an anti-cell death effect, which mainly improves survival and suppresses apoptosis (60). Usually, resistance to anticancer drugs is associated with a low propensity to apoptosis (61). Increased expression of anti-apoptotic proteins, including Bcl-2, has been noted in MDR cells $(42,62,63)$. Therefore, inhibition of Bcl-2 may be a strategy to overcome MDR. The present results demonstrated that $\mathrm{CuB}$ induced the apoptosis of A2780/Taxol cells in a dose-dependent manner, which was accompanied by decreased expression of pro-caspase- 3 and Bcl-2.

p53 is commonly considered as a tumor-suppressor gene, which can regulate genes involved in apoptosis and may modulate mitochondrial proteins, including $\mathrm{Bcl}-2$, Bcl-2-associated $\mathrm{X}$ protein, $\mathrm{Bcl}-2$ homologous antagonist/killer and Bcl-extra large, to promote the release of cytochrome $c$ and apoptosis (64). It may also induce cell cycle arrest and/or apoptosis in response to cellular stresses, including ionizing radiation, ultraviolet light, growth factor deprivation, reactive oxygen species and DNA damage induced by various cytotoxic agents (65). There has been accumulating evidence that the status of p53 has a significant impact on drug sensitivity (66-68). As confirmed by the present study, $\mathrm{CuB}$ treatment increases the protein levels of p53 and p21 in a dose-dependent manner.

In summary, to the best of our knowledge, the present study demonstrated for the first time that $\mathrm{CuB}$ can inhibit the growth of paclitaxel-resistant A2780/Taxol cells and induce cell apoptosis through upregulation of p53 and p21, downregulation of Bcl-2, activation of caspase-3 and suppression of P-gp. This compound may therefore provide an adjuvant therapy for the treatment of paclitaxel-resistant ovarian cancer. 


\section{Acknowledgements}

The present study was jointly sponsored by the Natural Science Foundation of China (grant no. 81473446), the Natural Science Foundation of Liaoning Province (grant no. 2013021081) and the Natural Science Foundation of Chongqing City (grant no. cstc2013jcyjA1587).

\section{References}

1. Bai X, Ma Y and Zhang G: Butein suppresses cervical cancer growth through the PI3K/AKT/mTOR pathway. Oncol Rep 33 3085-3092, 2015.

2. Arend RC, Londoño-Joshi AI, Straughn JM Jr and Buchsbaum DJ The Wnt/ $\beta$-catenin pathway in ovarian cancer: A review. Gynecol Oncol 131: 772-779, 2013

3. Arikan SK, Kasap B, Yetimalar H, Yildiz A, Sakarya DK and Tatar S: Impact of prognostic factors on survival rates in patients with ovarian carcinoma. Asian Pac J Cancer Prev 15: 6087-6094, 2014.

4. Li H, Zeng $\mathrm{J}$ and Shen K: PI3K/AKT/mTOR signaling pathway as a therapeutic target for ovarian cancer. Arch Gynecol Obstet 290 : 1067-1078, 2014

5. Muccioli M and Benencia F: Toll-like receptors in ovarian cancer as targets for immunotherapies. Front Immunol 5: 341, 2014.

6. Teo MC: Update on the management and the role of intraperitoneal chemotherapy for ovarian cancer. Curr Opin Obstet Gynecol 26: 3-8, 2013.

7. Wei W, Dizon D, Vathipadiekal V and Birrer MJ: Ovarian cancer: Genomic analysis. Ann Oncol 24 (Suppl 10): x7-x15, 2013.

8. Zhao Y, Gou WF, Chen S, Takano Y, Xiu YL and Zheng HC: BTG1 expression correlates with the pathogenesis and progression of ovarian carcinomas. Int J Mol Sci 14: 19670-19680, 2013

9. Bookman MA: First-line chemotherapy in epithelial ovarian cancer. Clin Obstet Gynecol 55: 96-113, 2012.

10. Raja FA, Counsell N, Colombo N, Pfisterer J, du Bois A, Parmar MK, Vergote IB, Gonzalez-Martin A, Alberts DS Plante M, et al: Platinum versus platinum-combination chemotherapy in platinum-sensitive recurrent ovarian cancer: A meta-analysis using individual patient data. Ann Oncol 24 3028-3034, 2013

11. Schwab CL, English DP, Roque DM and Santin AD: Taxanes: Their impact on gynecologic malignancy. Anticancer Drugs 25: 522-535, 2014

12. Pellicciotta I, Yang CP, Venditti CA, Goldberg GL and Shahabi S Response to microtubule-interacting agents in primary epithelial ovarian cancer cells. Cancer Cell Int 13: 33, 2013.

13. Sorbe B, Graflund M, Nygren L and Horvath G: A study of docetaxel weekly or every three weeks in combination with carboplatin as first line chemotherapy in epithelial ovarian cancer: Hematological and non-hematological toxicity profiles. Oncol Lett 5: 1140-1148, 2013

14. Colombo PE, Fabbro M, Theillet C, Bibeau F, Rouanet P and Ray-Coquard I: Sensitivity and resistance to treatment in the primary management of epithelial ovarian cancer. Crit Rev Oncol Hematol 89: 207-216, 2014

15. Leamon CP, Lovejoy CD and Nguyen B: Patient selection and targeted treatment in the management of platinum-resistant ovarian cancer. Pharmgenomics Pers Med 6: 113-125, 2013

16. Lopez J, Banerjee S and Kaye SB: New developments in the treatment of ovarian cancer-future perspectives. Ann Oncol 24 (Suppl 10): x69-x76, 2013.

17. Cort A and Ozben T: Natural product modulators to overcome multidrug resistance in cancer. Nutr Cancer 67: 411-423, 2015.

18. Si M, Zhao J, Li X, Tian JG, Li YG and Li JM: Reversion effects of curcumin on multidrug resistance of MNNG/HOS human osteosarcoma cells in vitro and in vivo through regulation of P-glycoprotein. Chin Med J (Engl) 126: 4116-4123, 2013.

19. Abdallah HM, Al-Abd AM, El-Dine RS and El-Halawany AM: P-glycoprotein inhibitors of natural origin as potential tumor chemo-sensitizers: A review. J Adv Res 6: 45-62, 2015.

20. Bansal T, Jaggi M, Khar RK and Talegaonkar S: Emerging significance of flavonoids as P-glycoprotein inhibitors in cancer chemotherapy. J Pharm Pharm Sci 12: 46-78, 2009.

21. Lee CH: Reversing agents for ATP-binding cassette drug transporters. Methods Mol Biol 596: 325-340, 2010.
22. Wu CP, Calcagno AM and Ambudkar SV: Reversal of ABC drug transporter-mediated multidrug resistance in cancer cells: Evaluation of current strategies. Curr Mol Pharmacol 1: 93-105, 2008.

23. Zhao BX, Sun YB, Wang SQ, Duan L, Huo QL, Ren F and Li GF: Grape seed procyanidin reversal of p-glycoprotein associated multi-drug resistance via down-regulation of $N F-\kappa B$ and MAPK/ERK mediated YB-1 activity in A2780/T cells. PLoS One 8: e71071, 2013.

24. Abouzeid AH, Patel NR, Sarisozen C and Torchilin VP Transferrin-targeted polymeric micelles co-loaded with curcumin and paclitaxel: Efficient killing of paclitaxel-resistant cancer cells. Pharm Res 31: 1938-1945, 2014.

25. Sarisozen C, Abouzeid AH and Torchilin VP: The effect of co-delivery of paclitaxel and curcumin by transferrin-targeted PEG-PE-based mixed micelles on resistant ovarian cancer in $3-\mathrm{D}$ spheroids and in vivo tumors. Eur J Pharm Biopharm 88: 539-550, 2014.

26. Yang YI, Lee KT, Park HJ, Kim TJ, Choi YS, Shih IeM and Choi JH: Tectorigenin sensitizes paclitaxel-resistant human ovarian cancer cells through downregulation of the Akt and NFкB pathway. Carcinogenesis 33: 2488-2498, 2012.

27. Li J, Liu P, Mao H, Wanga A and Zhang X: Emodin sensitizes paclitaxel-resistant human ovarian cancer cells to paclitaxel-induced apoptosis in vitro. Oncol Rep 21: 1605-1610, 2009.

28. Zhou L, Liu P, Chen B, Wang Y, Wang X, Chiriva Internati M, Wachtel MS and Frezza EE: Silibinin restores paclitaxel sensitivity to paclitaxel-resistant human ovarian carcinoma cells. Anticancer Res 28: 1119-1127, 2008

29. Iwanski GB, Lee DH, En-Gal S, Doan NB, Castor B, Vogt M, Toh M, Bokemeyer C, Said JW, Thoennissen NH and Koeffler HP: Cucurbitacin B, a novel in vivo potentiator of gemcitabine with low toxicity in the treatment of pancreatic cancer. Br J Pharmacol 160: 998-1007, 2010.

30. Aribi A, Gery S, Lee DH, Thoennissen NH, Thoennissen GB, Alvarez R, Ho Q, Lee K, Doan NB, Chan KT, et al: The triterpenoid cucurbitacin $\mathrm{B}$ augments the antiproliferative activity of chemotherapy in human breast cancer. Int J Cancer 132: 2730-2737, 2013

31. Dakeng S, Duangmano S, Jiratchariyakul W, U-Pratya Y, Bögler $\mathrm{O}$ and Patmasiriwat P: Inhibition of Wnt signaling by cucurbitacin B in breast cancer cells: Reduction of Wnt-associated proteins and reduced translocation of galectin-3-mediated $\beta$-catenin to the nucleus. J Cell Biochem 113: 49-60, 2012

32. Gao Y, Islam MS, Tian J, Lui VW and Xiao D: Inactivation of ATP citrate lyase by Cucurbitacin B: A bioactive compound from cucumber, inhibits prostate cancer growth. Cancer Lett 349: $15-25,2014$

33. Guo J, Wu G, Bao J, Hao W, Lu J and Chen X: Cucurbitacin B induced ATM-mediated DNA damage causes G2/M cell cycle arrest in a ROS-dependent manner. PLoS One 9: e88140, 2014.

34. Guo J, Zhao W, Hao W, Ren G, Lu J and Chen X: Cucurbitacin B induces DNA damage, G2/M phase arrest, and apoptosis mediated by reactive oxygen species (ROS) in leukemia K562 cells. Anticancer Agents Med Chem 14: 1146-1153, 2014.

35. Gupta P and Srivastava SK: Inhibition of integrin-HER2 signaling by Cucurbitacin B leads to in vitro and in vivo breast tumor growth suppression. Oncotarget 5: 1812-1828, 2014

36. Ma J, Zi Jiang Y, Shi H, Mi C, Li J, Xing Nan J, Wu X, Joon Lee J and Jin X: Cucurbitacin B inhibits the translational expression of hypoxia-inducible factor-1 $\alpha$. Eur J Pharmacol 723: 46-54, 2014.

37. Shang Y, Guo XX, Li WW, Rao W, Chen ML, Mu LN and Li SJ: Cucurbitacin-B inhibits neuroblastoma cell proliferation through up-regulation of PTEN. Eur Rev Med Pharmacol Sci 18: 3297-3303, 2014

38. Yin D, Wakimoto N, Xing H, Lu D, Huynh T, Wang X, Black KL and Koeffler HP: Cucurbitacin B markedly inhibits growth and rapidly affects the cytoskeleton in glioblastoma multiforme. Int J Cancer 123: 1364-1375, 2008.

39. Zhang M, Zhang H, Sun C, Shan X, Yang X, Li-Ling J and Deng Y: Targeted constitutive activation of signal transducer and activator of transcription 3 in human hepatocellular carcinoma cells by cucurbitacin B. Cancer Chemother Pharmacol 63: 635-642, 2009

40. Zhang M, Sun C, Shan X, Yang X, Li-Ling J and Deng Y: Inhibition of pancreatic cancer cell growth by cucurbitacin B through modulation of signal transducer and activator of transcription 3 signaling. Pancreas 39: 923-929, 2010. 
41. Zhang M, Bian ZG, Zhang Y, Wang JH, Kan L, Wang X, Niu HY and He P: Cucurbitacin B inhibits proliferation and induces apoptosis via STAT3 pathway inhibition in A549 lung cancer cells. Mol Med Rep 10: 2905-2911, 2014.

42. Zheng Q, Liu Y, Liu W, Ma F, Zhou Y, Chen M, Chang J, Wang Y, Yang $\mathrm{G}$ and $\mathrm{He} \mathrm{G}$ : Cucurbitacin B inhibits growth and induces apoptosis through the JAK2/STAT3 and MAPK pathways in SH-SY5Y human neuroblastoma cells. Mol Med Rep 10: 89-94, 2014.

43. Shi W, Li X, Hou X, Peng H, Jiang Q, Shi M, Ji Y, Liu X and Liu J: Differential apoptosis gene expressions of rhabdomyosarcoma cells in response to enterovirus 71 infection. BMC Infect Dis 12: 327, 2012.

44. Correia C, Lee SH, Meng XW, Vincelette ND, Knorr KL, Ding H, Nowakowski GS, Dai H and Kaufmann SH: Emerging understanding of Bcl-2 biology: Implications for neoplastic progression and treatment. Biochim Biophys Acta 1853: 1658-1671, 2015.

45. Schacter JL, Henson ES and Gibson SB: Estrogen regulation of anti-apoptotic Bcl-2 family member Mcl-1 expression in breast cancer cells. PLoS One 9: e100364, 2014.

46. Li C, Sun BQ and Gai XD: Compounds from Chinese herbal medicines as reversal agents for P-glycoprotein-mediated multidrug resistance in tumours. Clin Transl Oncol 16: 593-598, 2014

47. Seward SM and Winer I: Primary debulking surgery and neoadjuvant chemotherapy in the treatment of advanced epithelial ovarian carcinoma. Cancer Metastasis Rev 34: 5-10, 2015.

48. Januchowski R, Zawierucha P, Ruciński $M$ and Zabel $M$ : Microarray-based detection and expression analysis of extracellular matrix proteins in drug-resistant ovarian cancer cell lines. Oncol Rep 32: 1981-1990, 2014.

49. Huq F, Yu JQ, Beale P, Chan C, Arzuman L, Nessa MU and Mazumder ME: Combinations of platinums and selected phytochemicals as a means of overcoming resistance in ovarian cancer. Anticancer Res 34: 541-545, 2014

50. Saxena V and Hussain MD: Polymeric mixed micelles for delivery of curcumin to multidrug resistant ovarian cancer. J Biomed Nanotechnol 9: 1146-1154, 2013.

51. Ren Y, Yu K, Sun S, Li Z, Yuan J, Han XD, Shi J and Zhen L: JSI124 inhibits breast cancer cell growth by suppressing the function of B cells via the downregulation of signal transducer and activator of transcription 3. Oncol Lett 8: 928-932, 2014

52. Li JM, Zhang W, Su H, Wang YY, Tan CP, Ji LN and Mao ZW: Reversal of multidrug resistance in MCF-7/Adr cells by codelivery of doxorubicin and BCL2 siRNA using a folic acid-conjugated polyethylenimine hydroxypropyl- $\beta$-cyclodextrin nanocarrier. Int J Nanomedicine 10: 3147-3162, 2015.

53. Jansson PJ, Yamagishi T, Arvind A, Seebacher N, Gutierrez E, Stacy A, Maleki S, Sharp D, Sahni S and Richardson DR: Di-2-pyridylketone 4,4-dimethyl-3-thiosemicarbazone (Dp44mT) overcomes multidrug resistance by a novel mechanism involving the hijacking of lysosomal P-glycoprotein (Pgp). J Biol Chem 290: 9588-9603, 2015.

54. Drinberg V, Bitcover R, Rajchenbach W and Peer D: Modulating cancer multidrug resistance by sertraline in combination with a nanomedicine. Cancer Lett 354: 290-298, 2014.

55. Hu T, To KK, Wang L, Zhang L, Lu L, Shen J, Chan RL, Li M, Yeung JH and Cho CH: Reversal of P-glycoprotein (P-gp) mediated multidrug resistance in colon cancer cells by cryptotanshinone and dihydrotanshinone of Salvia miltiorrhiza. Phytomedicine 21: 1264-1272, 2014.
56. Januchowski R, Wojtowicz K, Sujka-Kordowska P Andrzejewska $M$ and Zabel M: MDR gene expression analysis of six drug-resistant ovarian cancer cell lines. Biomed Res Int 2013: 241763, 2013

57. Abraham J, Salama NN and Azab AK: The role of P-glycoprotein in drug resistance in multiple myeloma. Leuk Lymphoma 56 26-33, 2015

58. Tomiyasu H, Watanabe M, Sugita K, Goto-Koshino Y, Fujino Y, Ohno K, Sugano S and Tsujimoto H: Regulations of ABCB1 and ABCG2 expression through MAPK pathways in acute lymphoblastic leukemia cell lines. Anticancer Res 33: 5317-5323, 2013.

59. Vasconcelos FC, Silva KL, Souza PS, Silva LF, Moellmann-Coelho A, Klumb CE and Maia RC: Variation of MDR proteins expression and activity levels according to clinical status and evolution of CML patients. Cytometry B Clin Cytom 80: 158-166, 2011.

60. Vtorushin SV, Khristenko KY, Zavyalova MV, Perelmuter VM, Litviakov NV, Denisov EV, Dulesova AY and Cherdyntseva NV: The phenomenon of multi-drug resistance in the treatment of malignant tumors. Exp Oncol 36: 144-156, 2014.

61. Zhao H, Peng C, Ruan G, Zhou J, Li Y and Hai Y: Adenovirus-delivered PDCD5 counteracts adriamycin resistance of osteosarcoma cells through enhancing apoptosis and inhibiting Pgp. Int J Clin Exp Med 7: 5429-5436, 2014.

62. Ji T, Gong D, Han Z, Wei X, Yan Y, Ye F, Ding W, Wang J, Xia X, Li F, et al: Abrogation of constitutive Stat 3 activity circumvents cisplatin resistant ovarian cancer. Cancer Lett 341: 231-239, 2013.

63. Su J, Zhou L, Xia MH, Xu Y, Xiang XY and Sun LK: Bcl-2 family proteins are involved in the signal crosstalk between endoplasmic reticulum stress and mitochondrial dysfunction in tumor chemotherapy resistance. Biomed Res Int 2014: 234370, 2014.

64. Chakraborty S, Mazumdar M, Mukherjee S, Bhattacharjee P, Adhikary A, Manna A, Chakraborty S, Khan P, Sen A and Das T: Restoration of $\mathrm{p} 53 / \mathrm{miR}-34 \mathrm{a}$ regulatory axis decreases survival advantage and ensures Bax-dependent apoptosis of non-small cell lung carcinoma cells. FEBS Lett 588: 549-559, 2014.

65. Bykov VJ and Wiman KG: Mutant p53 reactivation by small molecules makes its way to the clinic. FEBS Lett 588: 2622-2627, 2014.

66. Vibhuti A, Muralidhar K and Dwarakanath BS: Differential cytotoxicity of the glycolytic inhibitor 2-deoxy-D-glucose in isogenic cell lines varying in their p53 status. J Cancer Res Ther 9: 686-692, 2013.

67. Schwermer M, Lee S, Köster J, van Maerken T, Stephan H, Eggert A, Morik K, Schulte JH and Schramm A: Sensitivity to cdk1-inhibition is modulated by $\mathrm{p} 53$ status in preclinical models of embryonal tumors. Oncotarget 6: 15425-15435, 2015.

68. Sabbatino F, Fusciello C, Somma D, Pacelli R, Poudel R, Pepin D, Leonardi A, Carlomagno C, Della Vittoria Scarpati G, Ferrone $S$ and Pepe S: Effect of p53 activity on the sensitivity of human glioblastoma cells to PARP-1 inhibitor in combination with topoisomerase I inhibitor or radiation. Cytometry A 85: 953-961, 2014 